\title{
Factors Affecting Constraints and Opportunities for Women Entrepreneurs in UAE - An Overview.
}

\author{
Dr Sneha Bhatia ${ }^{a}$ and Olivia Adkins ${ }^{b *}$ \\ ${ }^{a}$ Curtin Business School, Curtin University Dubai, United Arab Emirates, sneha.bhatia@curtindubai.ac.ae \\ ${ }^{b}$ Curtin Dubai Foundation Programme, Curtin University Dubai, United Arab Emirates, olivia.adkins@curtindubai.ac.ae \\ *Corresponding author.
}

Received: 15 October 2018, accepted: 18 October 2018, published: 3 Macrh 2019

\begin{abstract}
Women entrepreneurs increasingly contribute to the economic growth and creation of job opportunities today. Despite the opportunities that are present in countries such as the UAE, some women are still unable to pursue their entrepreneurial motives, due to the constraints that they face. The aim of the paper is to provide an overview of various factors affecting the constraints and opportunities for women entrepreneurs in UAE. While existing literature describes some studies unfolding the wave of entrepreneurship among women, the ones focusing specifically on UAE cluster are even fewer. The paper acknowledges the various efforts made the governments to promote and encourage women entrepreneurship, and highlights some of the barriers for women entrepreneurship as well as giving recommendation to address those gaps. The article makes use previous research conducted on the topic and acts as a spring board for further empirical research.
\end{abstract}

Keywords: Women entrepreneurs, Entrepreneurship, UAE

JEL codes:

\section{INTRODUCTION}

Over the past twenty years researchers have published more extensively on the subject of entrepreneurship among women than ever before (Marlow and McAdam, 2013; Verheul, Vanstel \& Thurik, 2006; Baughn, Chua \& Neupert, 2006; Klapper and Quesada Delgado 2007). This increased interest can be attributed to both the number of women entrepreneurs and their impact on economic growth and the creation of job opportunities (Verheul et al., 2006). However, even given the increased amount of publication on the topic of entrepreneurship and women, the literature is still limited as compared to studies of male entrepreneurs or entrepreneurship in general, which for many reasons is also very male focused. Further, the literature focusing specifically on female entrepreneurship in the United Arab Emirates (UAE) is even more limited. Scholars and academicians in an effort to explain the low representation of women in business in the UAE; conducted a number of empirical studies (Karim, 2001; Priess \& McCrohan, 2006; Erogul \& McCrohan, 2008; Goby \& Erogul, 2011; Itani et al., 2011; Madichie \& Gallant, 2012). The UAE has seen substantial and fast paced development in infrastructure as well as its economy. The UAE's success story has occurred concurrent with the growing status of Emirati women as partners and contributors in this remarkable nation-building process. The UAE is an Arab country with a per capita GDP of US\$ 41,476 (International Monetary Fund, 2018) and is ranked among the wealthiest nations in the world. According to the 2005 census, women account for 49.3 percent of the national population and are at the forefront of the workforce in the UAE in both the government sector as well as a growing number in the private sector. The UAE Ministry of State for Federal National Council Affairs (MFNCA) was established in 1971. Since then https://doi.org/10.30585/icabml-cp.v2i1.254

(c) 2018 the Authors. Production and hosting by Avicenna FZ LLC. on behalf of Dubai Business School, University of Dubai - United Arab Emirates. This is an open access article under the CC BY-NC license. 
successive governments of UAE have been committed to empower women by offering them equal opportunities and starting multiple initiatives to promote women led enterprises.

The Global Entrepreneurship Monitor (GEM, 2017) report ascertained the attitudes of the population in UAE; towards Entrepreneurship. Findings of the report labeled UAE as an innovation driven economy that stresses on venturing into new markets. The report also launches the GEM Entrepreneurial Spirit index which combines the following selfperception dimensions; "entrepreneurial awareness, opportunity perception and entrepreneurial self-efficacy". The UAE ranks seven out of fifty four in the Entrepreneurial Spirit Index. There is a realization that Small and Medium-Sized Enterprises (SMEs) act as one of the main catalysts in economic development. Thus, the government is trying to strengthen the private sector (Pistrui \& Fahed-Sreih, 2010) by encouraging diversification into hospitality, tourism, real estate, education, health care and more; thereby increasing stability of the nation's economy. It is apparent that women across the UAE today constitute a vital part of the workforce actively contributing to the country's economy and thus it becomes imperative to understand the rise of women entrepreneurs against this back drop.

\section{SIGNIFICANCE OF THIS RESEARCH}

While on one hand there is a clear progress in the government initiatives; on the other hand recent statistics do not look very positive. A report by IFC \& McKinsey (2011) suggests that women's representation in formal small and medium-sized enterprises (SMEs) in the Middle East is the lowest in the world. Preiss and McCrohan (2006) found that a mere $0.29 \%$ of women compared to $5.87 \%$ of men are involved with startup businesses in the UAE. Hence it evident that despite the governmental efforts women's entrepreneurial capacity remains substantially untapped. Thus it becomes imperative to better understand the factors influencing entrepreneurial behaviour of women in the nation. The purpose of this paper is to provide an overview of various factors affecting the constraints and opportunities for women entrepreneurs in UAE. While the paper acknowledges the multiple efforts that are being undertaken by the government to promote women entrepreneurship (and entrepreneurship in general); the researcher highlights the impediments for women entrepreneurs and gives recommendations to address the same. Through means of this paper, the scholars has urged various stakeholders (such as the government, family links/personal networks, Universities and Educational Institutions) to 'do their bit' in making UAE more conducive for all women entrepreneurs. This article relies heavily on secondary data but acts as a spring board for further empirical research.

\section{FACTORS INFLUENCING CONSTRAINTS AND OPPORTUNITIES FOR WOMEN ENTREPRENEURS}

\subsection{Push \& Pull factors influencing women's entrepreneurial drive:}

It is apparent that scholars and academicians across the globe have displayed keen interest in women's entrepreneurial behavior and how the escalation in the number of women-owned enterprises have created employment and economic development in various economies (Baughn, Chua \& Neupert, 2006; Verheul, Stel \& Thurik, 2006).

However, there are different circumstances (positive or negative) that may influence women to engage in entrepreneurial behaviour (Woldie and Adersua, 2004). Such factors can be termed as either push or pull factors (Marlow and Carter, 2004; Buttner and Moore, 1997; Robinson, 2001). The 'push' factors refer to negative circumstances such as low income, low job satisfaction, erratic work timings, lack of career progression which may push a woman to start her enterprise. 'Pull' factors represent one's entrepreneurial behaviour which be attributed to positive circumstances. These may include the desire to be independent, creative and risk taking ability, desire for a better work-life balance (Moore and Buttner, 1997; Moore, 2002). A study conducted by Erogul and McCrohan (2008) found that women in the UAE were under the spell of pull factors as their drive stemmed from their desire to be self-reliant and independent, develop their own entrepreneurial capacities and do well professionally while simultaneously giving back to the society. However, external factors such as social and environmental factors along with contexts in which these businesses function have a huge impact on the success of the enterprise (Bygrave, 1994). These have been elaborated in the subsequent sections.

\subsection{Influence of religious \& socio-cultural norms}

Roomi and Parrot (2008) suggest that the most of the challenges faced by female entrepreneurs emerge from the structure of the societies they operate in. Karim (2001) opines that socio-cultural factors such as religious values, ethnicity, and marital status have a huge impact on women's entrepreneurial decisions. UAE's founding father, Sheikh Zayed bin Sultan Al Nahyan, once stated that "Women have the right to work everywhere." Sheikh Zayed believed that 
women should work and contribute to society, but that this right would be based on merit and not favouritism, once stating that: "Like men, women deserve the right to occupy high positions according to their capabilities and qualifications" (MFNCA report, 2011). However, this vision is yet to be fully realised. UAE under the strong influence of Islamic Sharia law has been patriarchal in nature, thus making it male dominated in most walks of life. Despite the rapid makeover of their infrastructure and economies, most Arab countries still have a long way to go in terms of providing their women with equal social opportunities as men (Varadarajan, Gallant \& Majumdar, 2011). For example, in UAE, which has a high level of female education, the ratio of female participation in the workforce drops considerably. Statistics indicate about 70 percent of the UAE's university students were females, but their participation in the country's workforce was only around 22 percent (Ministry of Economy, UAE). There are various factors this trend could be attributed to. The strong influence of culture and religion impedes women from going beyond their traditional roles thus making it tough for women to exploit their business acumen (Priess \& Mcrohan, 2006; Goby \& Erogul 2011).

It is apparent in Figure 1, in Hofstede's cultural dimensions that UAE scores high on Uncertainty avoidance. This contrasts the very nature of entrepreneurs risk taking behaviour. Haan (2003) opines that an increased fear among Emirati women is the loss of credibility, which may lead them to let go of lucrative venture creation opportunities and take up stable government sector jobs instead. This fact was reinforced in a study conducted by Erogul \& McCrohan (2008) that people in UAE perceived jobs in the government sector as much more stable and secure and would much rather have their children take these government jobs than opting for the comparatively riskier options of setting up an enterprise. This coupled with the stigma associated to failure may act as a barrier for women entrepreneurs in the Emirates. According to Hofstede (2001), western or individualistic societies tend to display autonomy. This is in contrast with Arab countries which are collectivist societies that value group conformity and extended families form the core of the society. It is obvious why women in UAE perceive themselves as more dependent on others and feel obligated to look after their families in exchange for protection (Hofstede, 2001). This relative focus on group conformity discourages autonomy and thus impedes any sort of entrepreneurial behaviour (Mueller \& Thomas, 2001).

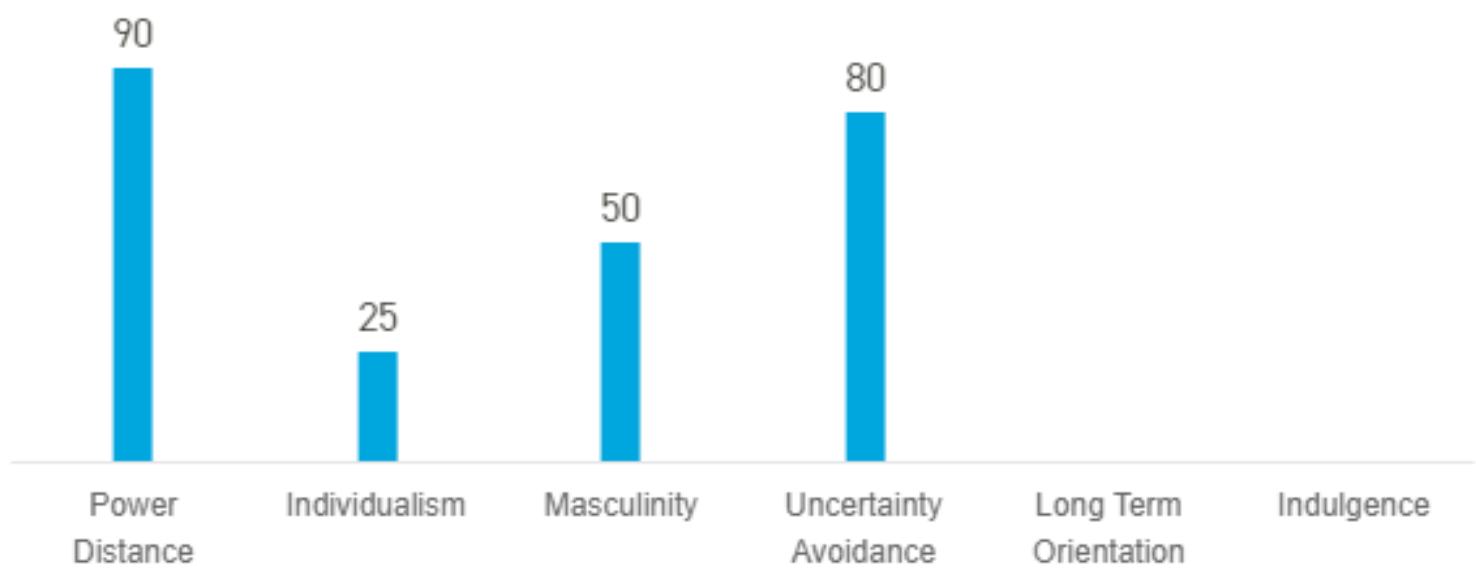

Figure 1: Overview of the UAE culture relative to other world cultures (Hofstede Insights).

\subsection{Support from family members}

Baud and Maghoub (1999) found that a considerable amount of Emarati women entrepreneurs wanted their families, especially husbands to be more supportive of them. Some potential women entrepreneurs may by discouraged by the male members of the family (Baud \& Maghoub, 1999). A decade later things don't seem to have changed much as Erogul and McCrohan's (2008) study revealed that 55\% of Emirati women receive support from their families, $27 \%$ of which receive help and support from the spouse. A study by Naser, Mohammed and Nuseibeh (2009) found that self-fulfillment, knowledge, skills and experience, including relationship to spouse/father business, are all important factors in the development of women entrepreneurs. The study also highlighted that the occupation of the father or the spouse had a strong influence over ones entrepreneurial capacity. If the father or the spouse enjoys a good social stance within the community and society, the women entrepreneur can leverage this position for her business and get loans easily (Naser et.al, 2009). This is also true for expats in Arab countries where most banks and financial institutions ask for a 'No 
objection Certificate' from the sponsor (father or spouse) to even open a bank account, let alone provide funding for a new venture creation.

\subsection{Access to capital}

Various studies around the world reported that lesser access to capital for women constituted one of the obstacles for women entrepreneurs (Itani, et al. 2011). Similarly, Madichie \& Gallant (2012) explained that lack of access to working capital is one of the main factors that constraints women entrepreneur. The participants of their study gave them insights on the various issues they were facing as well as the opportunities they had. In terms of access to capital, women seemed to be able to receive capital from their family, with their provision of financial assurance. Most of the women tend to use family resources since obtaining capital from the bank posed a challenge (Madichie \& Gallant, 2012). Moreover, Haan's (2004), qualitative research indicated that women faced issues securing capital during the start-up phase of their businesses. Even though there are various forms of support for women in the UAE to begin their entrepreneurial journey, the barriers are still quite present.

The Department of Economic Development in Dubai started the "Intelaq" programme, to assist Emiratis living in Dubai. The programme provides start-up support to small home-based projects through all its phases.

"Intelaq" is a one-of-a-kind programme launched in the UAE to assist Emiratis residing in Dubai to take their first step into the world of entrepreneurship through small projects in diverse areas practiced at home. The programme aims to provide aspiring business owners with company start-up support through all its phases. Haan (2004) recognises that the programme, solves a problem for entrepreneurial women who start with home businesses.

The ministry of state reported that women in the UAE manage a capital of 12.5 billion in various fields (Ministry of State for Federal National Council Affairs).

\subsection{Government interventions in UAE}

According to a government report, about half of the small-to-medium enterprise sector in the UAE is handled by women; further, 48 percent of women business-owners are also the sole owners of their firms (MFNCA report, 2011). Many businesses have trouble raising equity finance for their business proposals. To cater to this issue, UAE has set up incubators and innovation clusters to provide a spring board for budding entrepreneurs and potential business plans. This coincides with Sheikh Zayed's vision of turning Dubai into a hub of Innovation. UAE recognizes and addresses this need by creating entities to promote and support new ventures. The banking and financial sector encourages not just Emiratis but various expatriates to set up businesses in the different free zones in UAE. However this may be executed differently for women entrepreneurs. The government is trying to make it easier by simplifying procedures for new enterprise creation through various efforts. Initiatives such as establishing a business women's council in UAE and catalyzing funding venues to provide capital for women's start-ups (Goby \& Erogul, 2011), have eventuated in rising numbers of women entrepreneurs (Erogul \& McCrohan, 2008; Itani et al., 2011). These have been described in detail in the subsequent sections.

\subsubsection{Ease of doing business in UAE}

The World Bank Group Flagship Report, Doing Business 2018, provides "objective measures of business regulations and their enforcement across 190 economies and selected cities at the subnational and regional level." The report also ascertains the distance to frontier, which looks at how close a country is to the ideal for "ease of doing business". As can be seen in figure 1 , the UAE is $21^{\text {st }}$ in the world, and the best in the Middle East and North Africa region. 


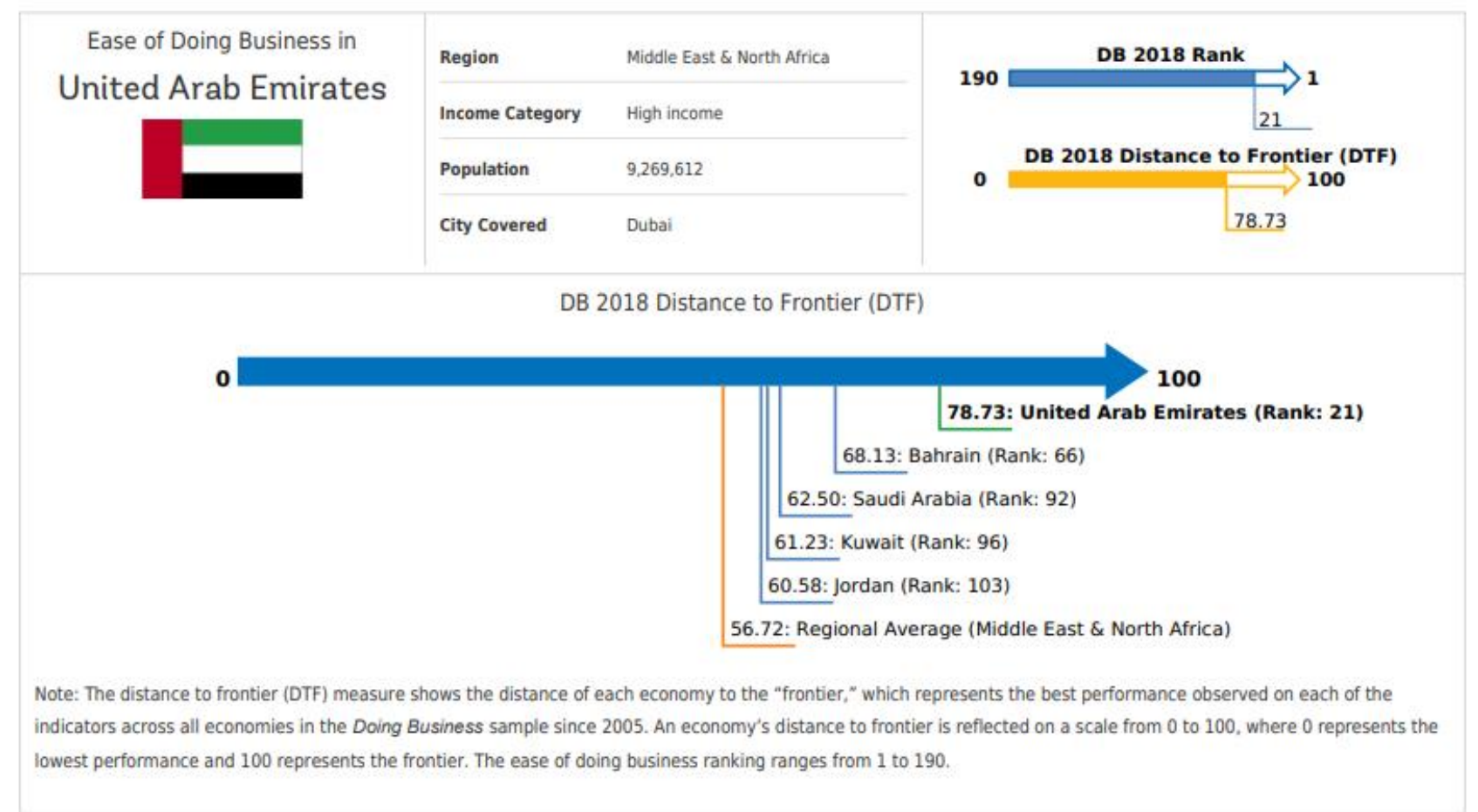

Figure 2: Ease of doing business in UAE (World Bank, 2018).

With the World Bank report, we also get a closer look at various doing business topics. It can be seen in Figure 3 , that the UAE ranks high, on topics such as electricity, taxes, getting construction permits, and lower on getting credit and trading across borders. This confirms one of the main constraints of women entrepreneurs of access to capital. Even though the UAE has taken measures to ensure doing business in the country is efficient and easy, getting credit still poses a problem which hinders the development of entrepreneurial activities and affects women more.

\section{Rankings on Doing Business topics - United Arab Emirates}

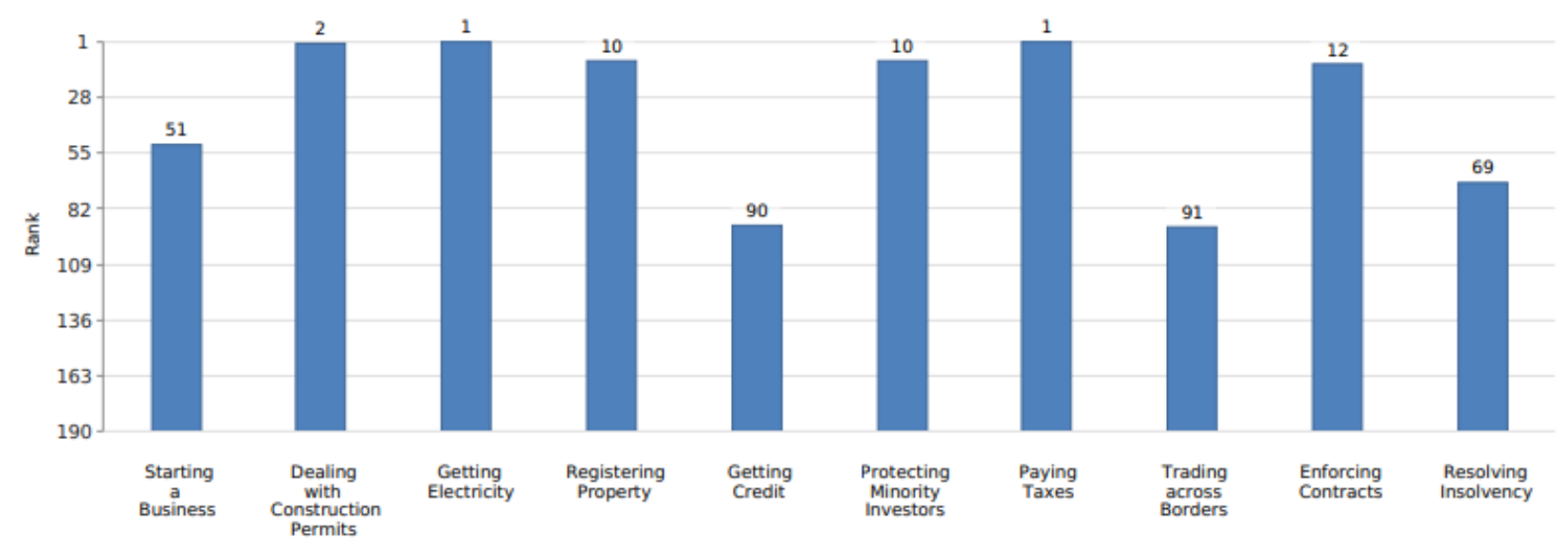

Figure 3: UAE's rankings on doing business topics (World Bank, 2018) 
In the UAE the formation of Innovation Clusters and Free zones serve as support systems for start - ups, where entrepreneurs are assisted in a supportive environment.

Dubai Creative Clusters Authority is an initiative "responsible for providing the regulation and policy framework to enable the growth and long-term competitiveness of Dubai Creative Clusters". Dubai Creative Clusters regulates a Free Zone consisting of 9 clusters spread over 7 industries. This makes starting business in the UAE easier, because each cluster brings together start-ups, talented workers and established leaders to collaborate in the hubs.

\subsubsection{Role of Dubai Business Women's council}

The government has taken various initiatives to increase the involvement of women and assist women in business. One of which has been the creation of the businesswomen's council in each of the Emirates (Goby and Erogul, 2011). These councils provide training on entrepreneurship and specific sources of help such as feasibility studies and consulting services for the setting up of businesses including securing finance for small and medium sized ventures. Various government institutions are training women in accounting, marketing, administration, and management of resources, leadership, and legal issues to help them succeed as entrepreneurs.

In Dubai, the Dubai Business Women Council DBWC is a non-profit group with strong backing from Dubai Chamber of Commerce \& Industry and other Dubai Government Departments. The chamber organises various conferences for women entrepreneurs. The Dubai Women's Council is open to residents and workers in the UAE and other countries, as well. The member's demographics are such that Middle East and GCC residents and workers only form $40 \%$ compared to the rest of the world. Moreover, employed executives and business owners are a formative part of the council.

This is an excellent initiative which gives the women the opportunity to network and communicate on topics such as entrepreneurship but also get training on various phases of the field. There needs to be more encouragement, within the country and towards aspiring business owners, to network with established owners and receive the support required.

\subsubsection{Mohammed bin Rashid Establishment for young business leaders}

The Mohammed Bun Rashid Establishment for Young business Leaders also known as Dubai SME, launched in 2002 and is a division of the Department of Economic Development. It serves as a resource "for support, information and outreach for the growing small and medium enterprise sector" (SME, 2018). The promotion of innovation and leadership are one of the major goals of the Dubai SME. To achieve their goals, they assist UAE Nationals with support through all the phases of starting a business.

According to Haan, the SME offers " (i) free trade licence for three years, (ii) a business centre with office space for 60 entrepreneurs, together with secretarial and telecommunications services, (iii) advisory services; (iv) special mentoring arrangements, ( $v$ ) in-house training, workshops and business forums; and (vi) access to resources, contacts and networks" (Haan, 2008).

\subsection{Role of education in fostering entrepreneurship}

There is a plethora of literature highlighting a positive correlation between entrepreneurship education \& perceived attractiveness and feasibility of new venture initiation (Tkachev and Kolvereid, 1999; Peterman and Kennedy, 2003; Fayolle and Lassas-Clerk, 2006; Souitaris et al., 2007). Vajardan, Gallant \& Majumdar (2010) opine that female students in UAE displayed immense interest in new ventures creation and recognized the crucial role of Universities in fostering their entrepreneurial and business acumen - this is apparent in mean scores of the UAE students which were higher than their international counterparts. The authors assert that entrepreneurship education may lead to increased entrepreneurial intentions and therefore to more new ventures being created (Vajardan et.al, 2010). The 2007 United Nations Development Programme (UNDP) status report on Millennium Development Goals acknowledged UAE's policies for empowering women. According to the findings of the report, educational indicators show that women's achievements in education have reached its targeted levels, and in some cases, exceeded that of men (MFNCA report, 2011). This fact was reiterated in the report compiled by Office of Higher Education, Policy and Planning, Ministry of Higher Education and Scientific Research (2007) indicating that women account for $70 \%$ of the graduates in the nation (MFNCA report, 2011). Mueller and Thomas (2001) state that "to be motivated to act, potential entrepreneurs must perceive themselves as capable and psychologically equipped to face the challenges of a global marketplace. Business education can play an 
important role in this regard by providing not only the technical expertise; but also reorient individuals towards selfreliance, independent action and creative thinking".

\section{RECOMMENDATIONS TO PROMOTE WOMEN'S ENTREPRENEURIAL PARTICIPATION IN UAE}

Families should be more supportive of female entrepreneurs, and more should be done to change the mind-sets of the wider population of the culturally perceived role of women. This would lead to not only more women entrepreneurs, but also better access to capital, as banks realise women's businesses are an asset. Female entrepreneurs are an economic power, however, they do not receive as much support from the bank as their male counterparts would. Banks still require a male guarantor for loans as well as NOCs from male parties. Some studies did find that women are more wary of taking loans than men, however, banks can work on loan schemes dedicated for women and entrepreneurs.

A lot of studies that were analysed, are largely focused on Emirati women, however, looking at expat women as entrepreneurs would also be well received, since expats form a greater number of the population in the United Arab Emirates. In this regards, working towards programmes such as the "Intelaq" which not only support emiratis, but also expats in the UAE, and eases the trade license procedures.

Women should also play a part in order for the rest of the population to open up the doors. This being said, women should be encouraged to participate more often in the initiatives organised by the government, and actively be part of the councils that have been created to ease business for them in the country. This would let women build their own network as opposed to rely heavily on personal networks. The existing omen entrepreneurs should act as mentor or budding entrepreneurs, and increase awareness about the support from the government.

One of the recommendations is for Universities, to actively participate in entrepreneurial activities, by creating on campus incubators, to assess potential business ideas, and provide guidance and training to the individuals who require it.

One of the biggest barriers to women entrepreneurship remains the stereotypes about the field and it being male oriented. It is important, that these stereotypes are addressed, and women are empowered, through conferences, publications, and general discussion with both genders.

It is also important that families and communities are encouraged to recognize the participation of women in the economic development. Even though the government does a lot, it is important that this issue is addressed as a society.

Further qualitative research should definitely be conducted on this topic to understand the driving forces and constraints of expatriates and emirati women entrepreneurs within all emirates of the UAE.

\section{DIRECTION FOR FUTURE RESEARCH}

The present paper suggests a few avenues for future research. While this paper is an overview of women entrepreneurial constraints and opportunities in the UAE, it was observed that most of the research conducted in the area had a restricted sample size. Moreover, the focus on the different papers was mostly towards nationals of the country who truly only form a very small percentage of a total population. Future research could examine the issues and opportunities for all women entrepreneurs in greater depth. Given the involvement of the government to promote such activities, future researchers could work with entities such as Dubai Chamber of Commerce, which would give access to a greater sample size and a more diverse participant group as well as a better platform to discuss the opportunities of women entrepreneurs in the UAE.

\section{CONCLUSION}

Various factors can be seen as conducive in fostering Entrepreneurship among women in the UAE. The government initiatives in the recent past to empower women in the business sector have been rampant. However, women need to learn to channelize these resources and policy reforms to their advantage. It is apparent from the various government 
initiatives that have sprung up in the last few decades along with the stats that indicate women having made considerable amount of progress in entrepreneurial spheres. In UAE, the presence of various conventional push and pull factors are influencing women to get out of their comfort zones and take calculated risks for their new businesses. The society is also trying to be more responsive by enabling women to actively participate in the economy. Exposure through escalating education opportunities is one of them- UAE has seen a tremendous growth in the Education arena. In the last few decades, numerous foreign and local universities have mushroomed in the nation. This is in line with His Highness Sheikh Zayed's (founding father of the nation) vision of making UAE an Educational hub. With more and more women graduating with higher degrees; women are seen displaying higher self-confidence and willingness to start businesses of their own. However, these will have little success given the collectivist culture and stringent social norms for women in Arab societies. All the efforts will remain futile till people are willing to embrace the change with respect to traditional roles of women in the society. Thus, even though the trends look positive and we are headed in the right direction; the change is far too slow and we have a long way to go to truly harness the potential of the 'other half' of the population.

\section{REFERENCES}

Alstete, J. (2003). Trends in corporate knowledge asset protection. Journal of Knowledge Management Practice, 4(1).

Baud, Isa \& Hala Khalid Mahgoub (April 1999), Toward Increasing National Female Participation in the Labour Force (Specialist Report \#2, National Strategy for Labour Force Development and Employment Project, Ministry of Labour and Social Services, Dubai, UAE).

Baughn, C.C., Chua, B.L. and Neupert, K.E. (2006). The normative context for women's participation in entrepreneruship: A multicountry study. Entrepreneurship Theory and Practice, 30(5), pp.687-708.

Baughn, C.C., Chua, B.L. and Neupert, K.E. (2006). The normative context for women's participation in entrepreneruship: A multicountry study. Entrepreneurship Theory and Practice, 30(5), pp.687-708.

Buttner, E.H. and Moore, D.P. (1997). Women's organizational exodus to entrepreneurship: self-reported motivations and correlates with success. Journal of small business management, 35, pp.34-46.

Bygrave, B. (1994). The portable MBA in entrepreneurship. New York: John Wiley \& Sons

Djankov, S., La Porta, R., Lopez-de-Silanes, F. and Shleifer, A. (2002). The regulation of entry. The quarterly Journal of economics, 117(1), pp.1-37.

Erogul, M.S. and McCrohan, D. (2008). Preliminary investigation of Emirati women entrepreneurs in the UAE. African Journal of Business Management, 2(10), pp.177-185.

Erogul, M.S. and McCrohan, D. (2008). Preliminary investigation of Emirati women entrepreneurs in the UAE. African Journal of Business Management, 2(10), pp.177-185.

GEM. (2017). Global Report 2016/2017. Global Entrepreneurship Research Association (GERA), London Business School, UK.

Goby, V.P. and Erogul, M.S. (2011). Female entrepreneurship in the United Arab Emirates: Legislative encouragements and cultural constraints. In Women's Studies International

Forum, 34 (4) pp. 329-334. Pergamon.

Haan, H.C. (2003). "Fingers of One Hand": Experiences of Small Businesses in the Northern Emirates. CLMRI.

Hofstede, G. (2001). Culture's consequences: Comparing values, behaviors, institutions and organizations across nations. Sage publications.

Hofstede Insights. (2018).https://www.hofstede-insights.com/

IMF. (2018). International Monetary Fund. https://www.imf.org/external/datamapper/NGDPDPC@WEO/OEMDC/ADVEC/WEOWOR_LD/ARE

Itani, H., Sidani, Y.M. and Baalbaki, I. (2011). United Arab Emirates female entrepreneurs: motivations and frustrations. Equality, Diversity and Inclusion: An International Journal, 30(5), pp.409- 424.

Karim, N.A. (2001). Jobs, gender and small enterprises in Bangladesh: factors affecting women entrepreneurs in small and cotage industries in Bangladesh (No. 993467103402676). International Labour Organization.

Klapper, L.F. and Quesada Delgado, J.M. (2007). World Bank Group Entrepreneurship Survey: Data

Overview.

Madichie, N.O. and Gallant, M. (2012). Broken silence: a commentary on women's entrepreneurship in the United Arab Emirates. The international journal of entrepreneurship and innovation, 13(2), pp.81-92. 
Marlow, S. and Carter, S. (2004). Accounting for change: Professional status, gender disadvantage and selfemployment. Women in Management Review, 19(1), pp.5-17.

Marlow, S. and McAdam, M. (2013). Gender and entrepreneurship: Advancing debate and challenging myths; exploring the mystery of the under-performing female entrepreneur. International Journal of Entrepreneurial Behavior \& Research, 19(1), pp.114124.

MFNCA. (2011). Women in the United Arab Emirates: A Portrait of Progress.

Moore, D.P. and Buttner, E.H. (1997). Women entrepreneurs: Moving beyond the glass ceiling. Sage Publications, Inc.

Moore, D.P. (2002). Boundaryless transitions: global entrepreneurial women challenge career concepts.

Mueller, S.L. and Thomas, A.S. (2001). Culture and entrepreneurial potential: A nine country study of locus of control and innovativeness. Journal of business venturing, 16(1), pp.51-75.

Naser, K., Rashid Mohammed, W. and Nuseibeh, R. (2009). Factors that affect women entrepreneurs: evidence from an emerging economy. International Journal of Organizational Analysis, 17(3), pp.225-247.

Pistrui, D. and Fahed-Sreih, J. (2010). Islam, entrepreneurship and business values in the Middle East. International Journal of Entrepreneurship and Innovation Management, 12(1), pp.107- 118.

Preiss, K. and McCrohan, D. (2006). Global Entrepreneurship Monitor Report in the United Arab Emirates. Dubai: Zayed University.

Robinson, S. (2001). An examination of entrepreneurial motives and their influence on the way rural women small business owners manage their employees. Journal of Developmental Entrepreneurship, 6(2), p.151.

Varadarajan Sowmya, D., Majumdar, S. and Gallant, M. (2010). Relevance of education for potential entrepreneurs: An international investigation. Journal of small business and enterprise development, 17(4), pp.626-640.

Verheul, I., Stel, A.V. and Thurik, R. (2006). Explaining female and male entrepreneurship at the country level. Entrepreneurship and regional development, 18(2), pp.151-183.

Verheul, I., Stel, A.V. and Thurik, R. (2006). Explaining female and male entrepreneurship at the country level. Entrepreneurship and regional development, 18(2), pp.151-183.

Woldie, A. and Adersua, A. (2004). Female entrepreneurs in a transitional economy: Businesswomen in Nigeria. International Journal of Social Economics, 31(1/2), pp.78-93.

World Bank. (2018). World Bank Flagship Report. Doing Business 2018. http://www.doingbusiness.org/content/dam/doingBusiness/country/u/united-arab-emirates/ARE.pdf 